\title{
MANAJEMEN RISIKO WISATAWAN TANGGUH BENCANA DI KAWASAN WISATA ALAM MELALUI PENDEKATAN EDUWISATA (STUDI KASUS: HULU DAS ASAHAN DI SUMATERA UTARA)
}

\author{
Sylvia Aldriani', Johan Budi Andra² \\ 'Ganesha Operation Kisaran \\ Jl. Sisingamangaraja No.318, Asahan, Indonesia \\ 2Jurusan Pendidikan Geografi, Fakultas Ilmu Sosial, Universitas Negeri Medan \\ J. Willem Iskandar Pasar Lima Medan Estate 20221, \\ Email corresponding: johanbudiandra@gmail.com
}

\begin{abstract}
This research was conducted in Upstream of Asahan Watershed, Asahan Regency and Toba Samosir Regency, North Sumatera in 2018. This study aims to identify the potency of natural tourism as edutoursim in Upstream Asahan watershed and to map distribution of edutourism area. The population is Upstream of Asahan Watershed. The data are collacted by using survey techniques and documentary studies. Data processing techniques are descriptive. The instruments used are nature tourism, access attractions are Asahan Regency and Toba Samosir Regency, activity potential in tourist attraction.

Edutourism potential is Ponot Waterfall, Sigura-Gura Dam, Siharimo Waterfall, Asahan River, Asahan Hydro Power Plant, Baturangin Waterfall. Access to attraction through Toba Samosir Regency and Asahan Regency. Potential activities in tourism objects such as outbound activities, physical science research (geology, geomorphology, hydrology, fisheries, agriculture, plantations, disaster mitigation, and biology), social studies (indigenous peoples, livelihoods or economic systems, population activities, residential areas), camping areas, trekking, rafting sports, selling souvenirs in the tourist area.
\end{abstract}

Keywords: Potential Area, Edutourism, Asahan River

\begin{abstract}
Abstrak
Penelitian ini dilaksanakan di Hulu DAS Asahan, Kabupaten Asahan dan Kabupaten Toba Samosir, Sumatera Utara. Penelitian ini bertujuan untuk mengidentifikasi wisata alam berpotensi sebagai kawasan eduwisata di Hulu DAS Asahan dan memetakan sebaran potensi kawasan eduwisata di Hulu DAS Asahan. Populasi dalam penelitian ini adalah Hulu DAS Asahan. Teknik pengumpulan data dengan teknik survei dan studi dokumenter. Teknik pengolahan data secara deskriptif. Instrumen yang digunakan adalah wisata alam, akses menuju tempat wisata, potensi aktivitas di objek wisata.

Potensi eduwisata adalah Air Terjun Ponot, Bendungan Sigura-Gura, Air Terjun Siharimo, Sungai Asahan, Gardu PLTA Asahan, Air Terjun Baturangin. Akses menuju objek wisata strategis di jalur Kabupaten Toba Samosir dan Kabupaten Asahan. Potensi aktivitas di objek wisata seperti kegiatan outbond, penelitian sains fisik (geologi, geomorfologi, hidrologi, perikanan, pertanian, perkebunan, mitigasi bencana, dan biologi), penelitian sosial (masyarakat adat, jenis mata pencarian atau sitem perekonomian, aktivitas penduduk, dan pola pemukiman), area berkemah, tracking, olahraga arung jeram, berjualan cinderamata di area wisata.
\end{abstract}

Kata kunci : Potensi Area, Eduwisata, Sungai Asahan 


\section{PENDAHULUAN}

Menurut Tkachuk (dalam Akhmedova, 2016) Edutourism (Educational Tourism) adalah sebuah perjalanan, setelah wisatawan mengombinasikan waktu luang dan belajar, seperti menghadiri kelas, arahan untuk mengembangkan keterbatasan pengetahuan, memuaskan keingintahuan, dan mencapai tujuan pembelajaran. Teori tersebut menyatakan perjalanan berbasis pembelajaran bertujuan untuk bermacam-macam pembelajaran dan melengkapi sarana belajar, khususnya permintaan media pembelajaran, hasil produk wisata (pembelajaran dan buah tangan), keramahan pemandu dan masyarakat lokal, serta siklus dan kelanjutan pengembangan dari peminat wisata berbasis edukasi. Menurut Ritchie (dalam Akhmedova, 2016) menyatakan wisata berbasis edukasi adalah produk, proses dan fungsi. Produk menghasilkan pengalaman (belajar berkelompok, kuliah lapangan, pertukaran pelajar). Proses atau fungsi berfokus pada cara pembelajaran yang tidak berakhir seperti mengembangkan fokus terhadap penguasaan dan meningkatkan pengetahuan yang telah dimiliki.

Potensi eduwisata di Hulu DAS Asahan, Kabupaten Asahan didominasi wisata alam. Kawasan Hulu DAS Asahan berada di Kabupaten Toba Samosir dan Kabupaten Asahan, Sumatera Utara. Potensi eduwisata meliputi aliran Sungai Asahan, Air Terjun Ponot, Air Terjun Baturangin, Air Terjun Siharimo, Bendungan Sigura-gura, dan Gardu PLTA Asahan. Masyarakat dan BUMDes (Badan Usaha Milik Desa) mengembangkan potensi tersebut sebagai wisata alam. Potensi eduwisata tersebut belum dikembangkan secara maksimal dan menyeluruh oleh pemerintah dan masyarakat terkait keamanannya. Tujuan penelitian ini untuk mengidentifikasi potensi eduwisata di Hulu DAS Asahan, sebaran potensi eduwisata, program wisatawan tangguh bencana.

\section{METODOLOGI}

Alat-alat yang digunakan untuk mendukung penelitian ini adalah GPS, kamera digital, alat tulis, dan Google Earth Pro. Bahan yang digunakan untuk mendukung penelitian ini adalah citra alur Sungai Asahan dan citra persebaran lokasi potensi eduwisata.
Teknik pengumpulan data, yaitu teknik observasi langsung. Observasi langsung untuk menemukan potensi eduwisata di Hulu DAS Asahan dan memetakan persebaran potensi eduwisata. Studi dokumenter untuk pengambilan citra yang dibutuhkan dari Google Earth. Variabel yang digunakan dalam penelitian ini ialah objek berpotensi sebagai wisata berbasis pendidikan yang mudah diakses, ketersediaan akomodasi, fasilitas, transportasi, aktivitas rekreasi, komunikasi, perbankan, kesehatan, sarana ibadah, sarana olahraga, sarana pendidikan.

Teknik analisis data yang digunakan dalam penelitian ini adalah teknik analisis deskriptif. Data diperoleh dari hasil observasi lapangan yang berpotensi menjadi wisata berbasis pendidikan dan memetakan sebarannya berdasarkan zona dari rute perjalanan menuju daerah wisata.

\section{HASIL DAN PEMBAHASAN}

Bahan yang digunakan untuk mendukung penelitian ini adalah Peta DAS Asahan (BPDAS Barumun 2016) dan citra persebaran lokasi potensi eduwisata.

\section{Potensi Eduwisata Sungai Asahan}

Objek yang berpotensi sebagai eduwisata ialah Sungai Asahan, Air Terjun Ponot, Air Terjun Baturangin, Air Terjun Siharimo, Bendungan Sigura-gura, dan Gardu PLTA Asahan.

\section{Sungai Asahan}

Sungai Asahan merupakan sungai yang mengalir dari Danau Toba menuju ke Selat Malaka. Sungai Asahan memiliki panjang aliran adalah $147 \mathrm{~km}$ dan luas DAS (Daerah Aliran Sungai) sekitar $3.741 \mathrm{~km}^{2}$. Sungai Asahan mengaliri 4 kabupaten, yaitu Kabupaten Toba Samosir, Kabupaten Simalungun, Kabupaten Asahan, dan Kota Tanjung Balai. Sungai Asahan memiliki kedalaman rata-rata 5 meter dan jeram tingkat 4 ke 5 dari skala 1 sampai 6.

Sungai Asahan berpotensi sebagai arena olahraga dan studi morfologi sungai. Sungai Asahan bersama FAJI (Federasi Arung Jeram Indonesia) telah melakukan kerjasama untuk mengembangkan potensi dengan mengadakan Asahan Whitewater Festival 2007 (FAJl.org 2007). 


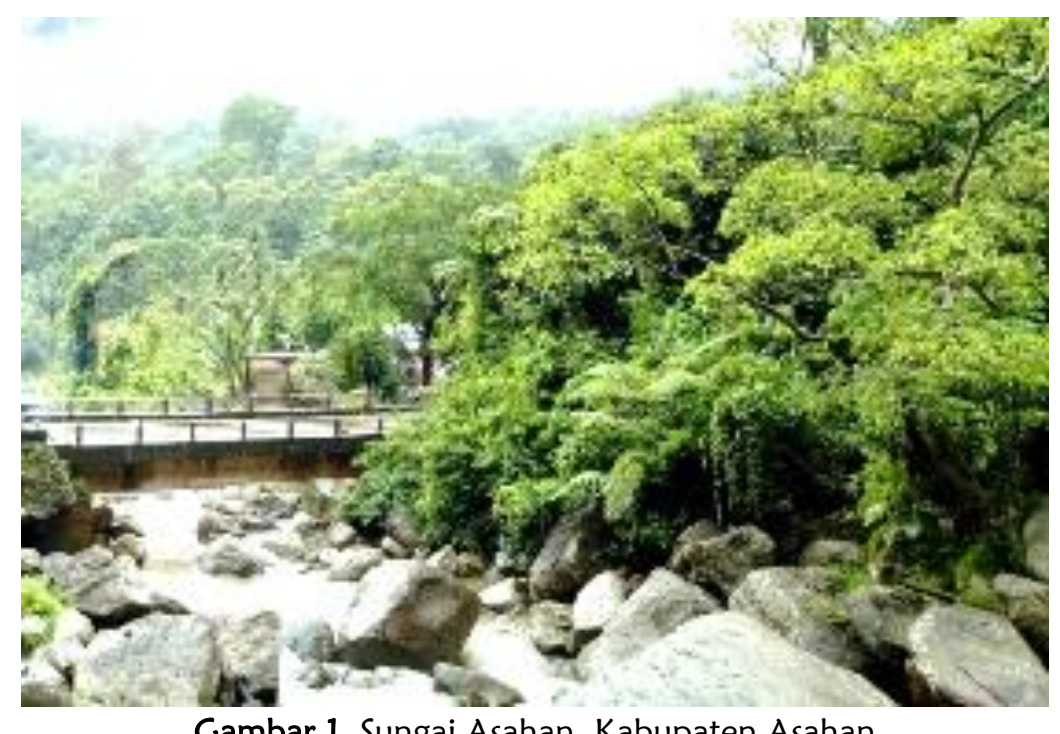

\section{Air Terjun Ponot}

Air Terjun Ponot berlokasi di Desa Tangga, Kecamatan Aek Songsongan, Kabupaten Toba Samosir. Air Terjun Ponot merupakan air terjun tertinggi di Indonesia dengan ketinggian sekitar 250 meter. Air Terjun Ponot berpotensi sebagai laboratorium fisik dan sosial. Potensi studi fisik seperti pembelajaran geomorfologi air terjun, geologi, biogeografi, hidrologi, mitigasi bencana, sedangkan potensi studi secara sosial seperti pola pemukiman, mata pencarian, adat istiadat. Air Terjun Ponot dikelola oleh BUMDes (Badan Usaha Milik Desa) Mekar Sari Desa Tangga. Keadaan wisata ini kurang tertata rapi karena warung yang didirikan sembarangan, pungutan liar di sepanjang perjalanan menuju objek wisata, dan pemeliharaan lokasi wisata yang kurang seperti pengawas kebersihan.

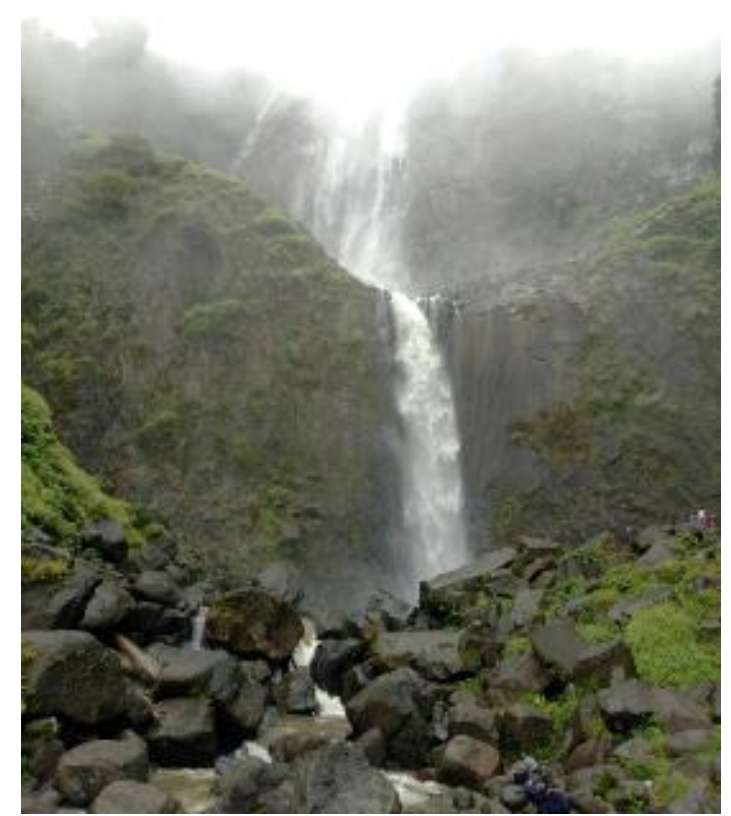

Gambar 2. Air Terjun Ponot, Kabupaten Asahan

\section{Air Terjun Siharimo}

Air Terjun Siharimo berlokasi di Desa Parhitean, Kecamatan Pintu Pohan, Kabupaten Toba Samosir.
Rute menuju air terjun ini dengan 2 jalur, yaitu dari Desa Parhitean (kondisi jalan rusak) atau melalui Desa Tangga, Kecamatan Aek Songsongan, 
Kabupaten Asahan. Air Terjun Siharimo berjarak 1 km dari Air Terjun Ponot. Air terjun ini memiliki debit air yang lebih kecil dan tenang dari Air Terjun Ponot.

Air Terjun Siharimo berpotensi sebagai sarana outbond seperti flying fox, arung jeram, dan sampan dayung. Potensi pembelajaran sains seperti studi hidrologi, geologi, mitigasi bencana, biogeografi, geomorfologi, dan konservasi. Potensi olahraga panjat tebing karena struktur batuannya keras, memiliki sudut hingga $90^{\circ}$, dan celah tebing yang dapat dijadikan pegangan. Wisata ini telah dibangun tangga dari tempat parkiran ke kolam air terjun, pos wisata, cakruk atau pondok bersantai, dan kamar mandi. Fasilitas tersebut belum beroperasi maksimal karena kurangnya perawatan dan promosi wisata. Air terjun ini kurang dikelola karena akses jalan batu padas lepas sehingga musim hujan menyebabkan jalanan licin.

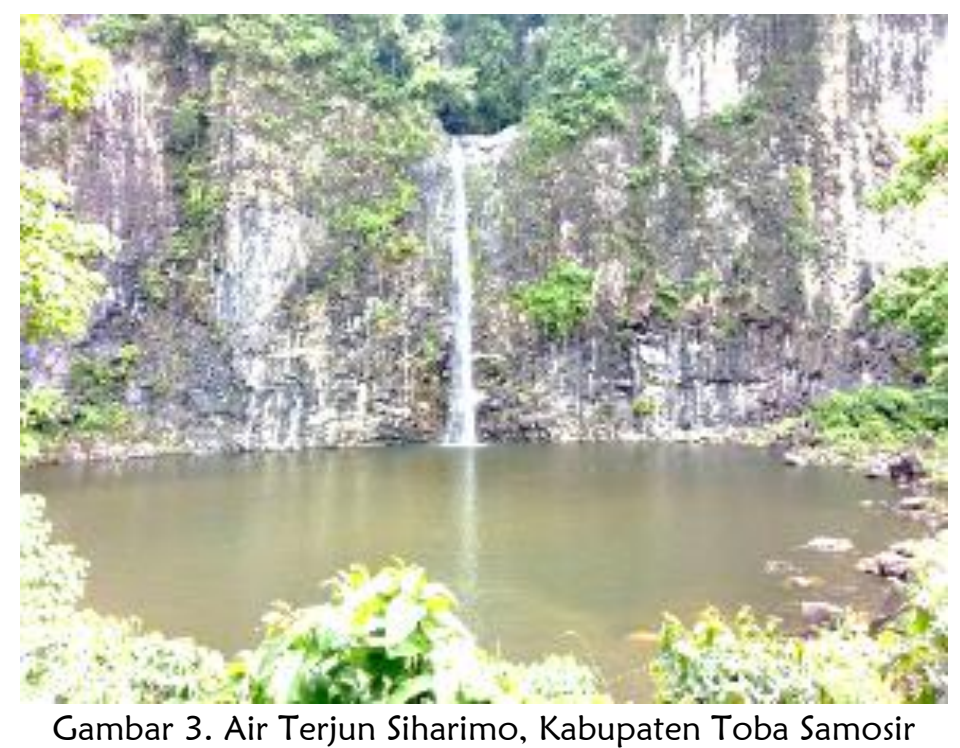

\section{Air Terjun Baturangin}

Air Terjun Baturangin berlokasi di Desa Meranti Utara, Kecamatan Pintu Pohan, Kabupaten Toba Samosir. Air terjun ini terletak bersebrangan dengan Air Terjun Sihariomo dari jalan utama. Debit air kecil di Air Terjun Baturangin. Akses menuju air terjun ini belum mendukung karena kondisi jalan batu padas lepas.
Air Terjun Baturangin berpotensi sebagai kolam pemandian dan studi sains seperti hidrologi, biogeografi, geologi, konservasi, dan geomorfologi. Air Terjun Baturangin belum dikelola oleh pihak swasta maupun pemerintah.

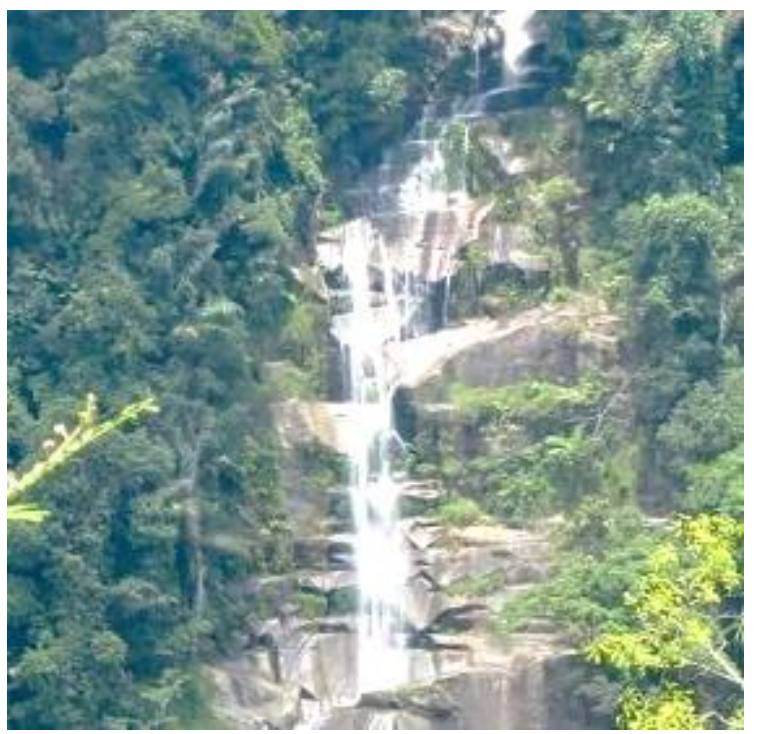

Gambar 4. Air Terjun Baturangin, Kabupaten Asahan 


\section{Bendungan Sigura-Gura}

Bendungan Sigura-gura berlokasi di hulu Sungai Asahan. Bendungan ini merupakan yang terbesar di Indonesia dengan tinggi 46m. Bendungan Sigura-gura dimanfaatkan sebagai Pembangkit Listrik Tenaga Air (PLTA) dibangun oleh PT. Inalum (Indonesia Aluminium).
Bendungan berpotensi sebagai media pembelajaran cara kerja air dibendungan diubah menjadi tenaga listrik sebagai sumber energi alternatif dan terbarukan. Pembelajaran dapat dilakukan dengan izin kunjungan memasuki area, membuat plang keterangan wilayah bendungan, dan pemasangan tanda bahaya.

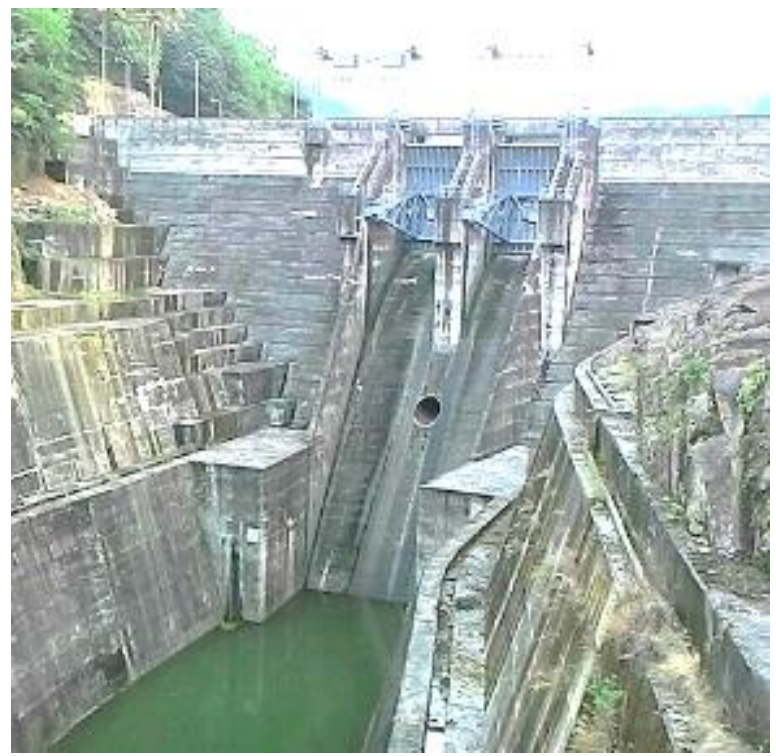

Gambar 5. Bendungan Sigura-Gura

\section{Gardu PLTA Asahan}

Gardu Induk PLTA Sigura-Gura Tangga merupakan pemasok tenaga listrik di Sumatera Utara. PLTA memanfaatkan Bendungan SiguraGura sebagai sumber daya dan debit aliran Sungai Asahan. Gardu PLTA berpotensi sebagai pembelajaran pemanfaatan air sungai sebagai Pembangkit Listrik Tenaga Air (PLTA) dan ancaman bencana di area PLTA. PLTA ASAHAN dibagi menjadi PLTA Asahan I berlokasi di hulu Sungai Asahan, Kabupaten Toba Samosir, Sumatera Utara yang dibangun Tahun 2011. PLTA
Asahan II berlokasi site PT INALUM di Desa Paritohan, Kecamatan Pintu Pohan Meranti, Kabupten Toba Samosir, Sumatera Utara yang dibangun Tahun 2013. PLTA Asahan III berlokasi di Dusun Mamak, Desa Tangga, Kecamatan Aek Songsongan, Kabupaten Asahan, Sumatera Utara yang dibangun Tahun 2016. PLTA Asahan IV berlokasi di Desa Tangga dan Desa Lubu Rappa, Kecamatan Aek Songsongan, Kabupaten Asahan, Sumatera Utara.

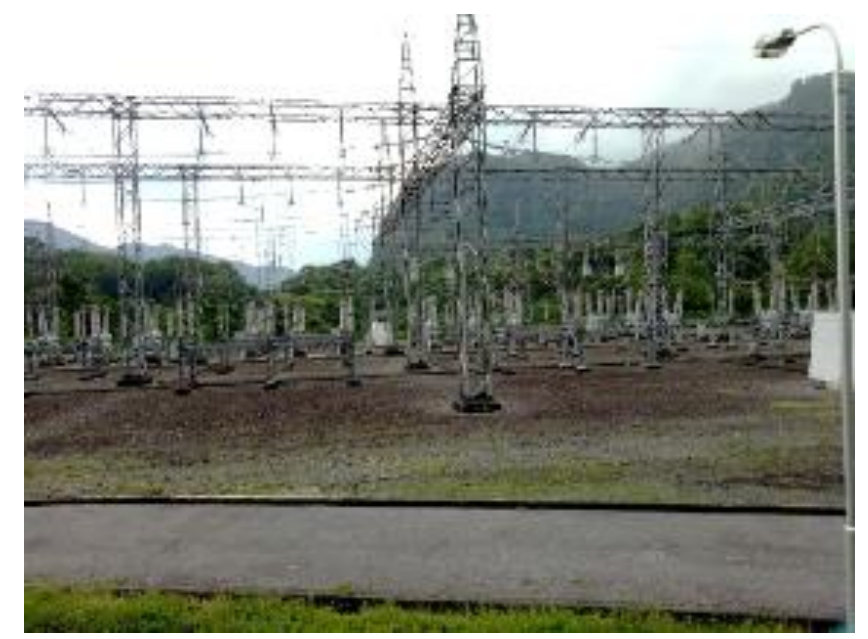

Gambar 6. Gardu Induk PLTA Asahan 


\section{Sebaran Potensi Eduwisata Sungai Asahan}

Potensi lokasi eduwisata Hulu DAS Asahan ialah jenis wisata hidrologi yang terdiri dari sungai, PLTA, dan air terjun. Potensi tersebut berlokasi di Hulu Sungai Asahan mencakup Kabupaten Asahan dan Kabupaten Toba Samosir. Potensi tersebut antara lain Sungai Asahan, Air Terjun Ponot, Air Terjun Baturangin, Air Terjun Siharimo, Bendungan Sigura-gura, dan Gardu PLTA Siguragura. Potensi dapat dimanfaatkan untuk kegiatan berolahraga, penelitian sains (biologi, ekologi, geomorfologi, sosial, mitigasi bencana, dan geologi), dan wisata air.

Sebaran potensi eduwisata dibagi menjadi 2 jalur berdasarkan akses menuju tempat wisata. Akses dapat melalui Desa Tangga, Kecamatan Aek Songsongan, Kabupaten Asahan atau melalui Desa Parhitean, Kecamatan Pintu Pohan, Kabupaten Toba Samosir. Jalur satu melalui Kabupaten Asahan terdapat objek Gardu PLTA Asahan, Air Terjun Ponot, Air Terjun Siharimo, dan Air Terjun Baturangin. Jalur dua melalui Kabupaten Toba Samosir, Bendungan Sigura-gura, Gardu PLTA Asahan, Air Terjun Ponot, Air Terjun Siharimo, dan Air Terjun Baturangin. Sungai Asahan mengaliri daerah di jalur satu dan jalur dua menuju ke Selat
Malaka. Peta sebaran potensi Hulu DAS Asahan pada Gambar 7.

\section{Program Masyarakat Tangguh Bencana}

Indonesia sebagai negara kepulauan dan didominasi wisata alam air kurang mendapat perhatian dari pengelola maupun pemerintah setempat. Kegiatan berwisata membutuhkan program masyarakat tangguh bencana yang disesuaikan berdasarkan intensitas kecelakaan ataupun bencana yang terjadi di tempat wisata. Bencana terjadi akibat kelalaian manusia ataupun keadaan alam yang tidak dapat diduga pengunjung. Masyarakat dibantu pemerintah dalam mengelola tempat wisata kurang memerhatikan keamanan dan menanamkan edukasi kepada wisatawan tingkat risiko terjadinya bencana dan area berpotensi terjadi bencana. Tempat wisata memiliki standar kelayakan yang aman dan nyaman bagi pengunjungnya agar tidak berujung bencana. Berikut standar kelayakan daerah tujuan wisata yang perlu dipertimbangkan pengelola, masyarakat setempat, pemerintah daerah, dan wisatawan.

Tabel 1. Standar Kelayakan Daerah Tujuan Wisata

\begin{tabular}{|c|l|l|}
\hline No. & \multicolumn{1}{|c|}{ Kriteria } & \multicolumn{1}{c|}{ Keterangan } \\
\hline 1 & Objek & Salah Satu Unsur Alam/ Sosial/ Budaya \\
\hline 2 & Akses & Jalan, Rute, Parkir, Harga Parkir \\
\hline 3 & Akomodasi & Penginapan (Hotel, Losmen, Wisma) \\
\hline 4 & Fasilitas & Plang Wisata, Pusat Informasi, Pemandu \\
\hline 5 & Transportasi & Transportasi Tersedia \\
\hline 6 & Catering Service & Makanan Dan Minuman(Warung/ Restoran) \\
\hline 7 & Aktivitas Rekreasi & Berenang, Mandi, Berfoto, Outbond \\
\hline 8 & Pembelanjaan & Membeli Cindera Mata \\
\hline 9 & Komunikasi & Sinyal, Penjual Pulsa, Televisi, Telepon \\
\hline 10 & Sistem Perbankan & ATM Bersama \\
\hline 11 & Kesehatan & Puskesmas, Tenaga Kesehatan, Obat \\
\hline 12 & Keamanan & Pengawas Wisata, Rambu-rambu Bahaya \\
\hline 13 & Kebersihan & Tempat Sampah dan Rambu Kebersihan \\
\hline 14 & Sarana Ibadah & Tempat Ibadah \\
\hline 15 & Sarana Pendidikan & Museum Mini untuk Wisatawan \\
\hline 16 & Sarana Olahraga & Perlengkapan Outbond \\
\hline
\end{tabular}

Sumber: Yoeti (1996)

Berdasarkan tabel di atas, Kawasan Wisata Alam di DAS Asahan belum sepenuhnya memenuhi standar layak, aman, dan nyaman bagi pengunjung. Pengunjung perlu mendapat edukasi dari ketersediaan fasilitas dan tenaga ahli yang tersedia. Pengelola dapat menarik minat wisatawan untuk belajar sekaligus berwisata dengan menambahkan museum mini yang merupakan bagian penting dari Kawasan Potensi Eduwisata. Museum mini menjadi pusat informasi, 
seperti peta lokasi, informasi geomorfologi, biogeografi, konservasi, dan sumber data penelitian maupun pembelajaran. Museum mini dapat mengedukasi pengunjung khususnya anakanak untuk belajar secara langsung dan mengenali kekayaan alam di daerah.

Standar kelayakan wisata dan kepedulian masyarakat terhadap keamanan tempat wisata kurang diperhatikan sehingga menimbulkan korban jiwa. Wisatawan tidak secara keseluruhan masyarakat asli di sekitar tempat wisata, sehingga kurang menyadari lokasi yang berbahaya untuk dijadikan area berwisata.

Dilansir dari berita online republika, seorang wisatawan tewas seusai mandi di sekitar air terjun.

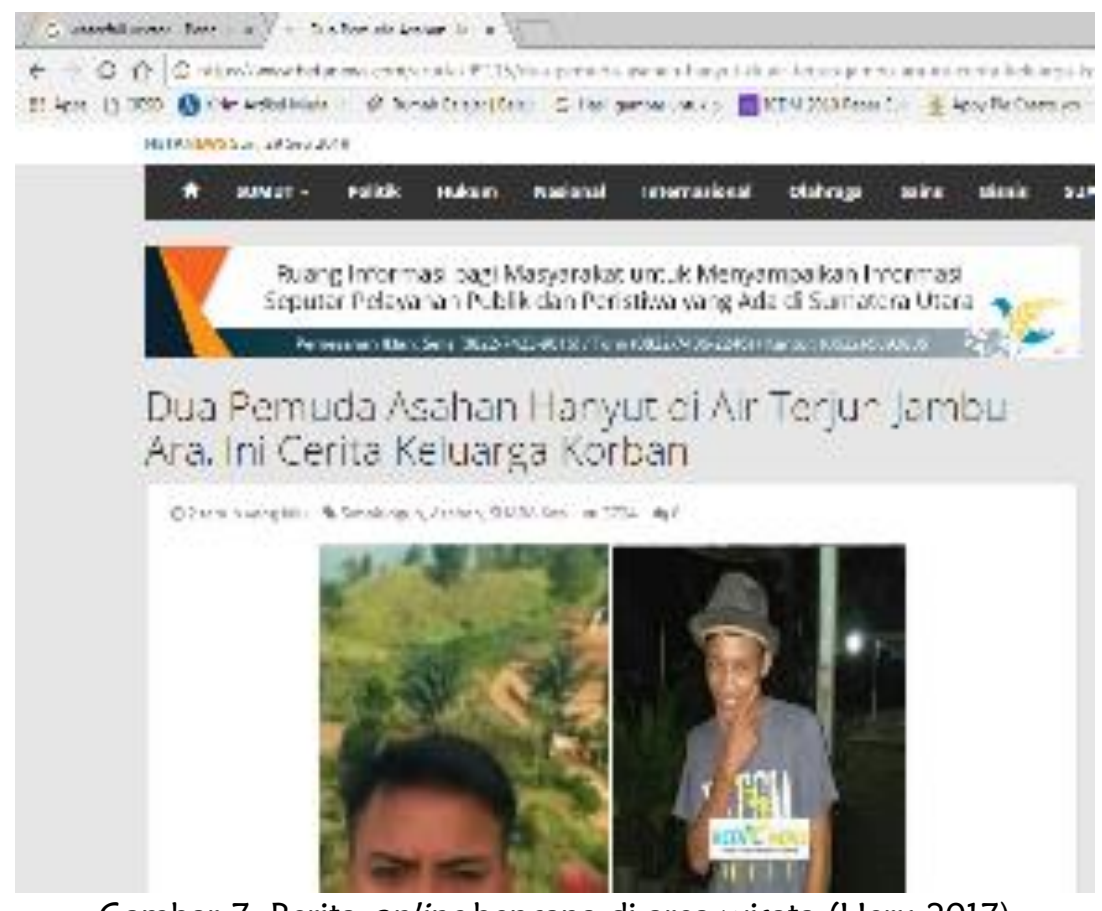

Gambar 7. Berita online bencana di area wisata (Heru 2017)

Menurut Reley, E (dalam Yudistira \& Susanto, 2012) ancaman risiko terbesar di tempat wisata disebabkan: (1) Bencana alam melalui perubahan cuaca dan kelalaian pengunjung sendiri (2) adanya tindakan pihak lain yang berada di tempat wisata yang merugikan pengunjung misalnya pembunuhan. Bencana di tempat wisata didominasi karena kurangnya informasi daerah bahaya di sekitaran wisata. Menurut The Worker's Compensation Board (WCB) of British Columbia (dalam Yudistira, I.G.A. Anom, 2012) Health and Safety Program adalah semua kegiatan yang meliputi pengembangan proses, seperti: (1) perencanaan manajemen risiko dengan melakukan identifikasi hingga memberlakukan proses manajemen risiko, (2) perencanaan pariwisata dengan memberlakukan prosedur yang akan menjamin keselamatan pengunjung, (3) perencanaan respon tanggap darurat apabila munculnya kecelakaan yang terjadi di tempat wisata, (4) aturan dan prosedur dalam menghadapi kecelakaan yang terjadi dengan mengutamakan keselamatan dan keamanan pengunjung, (5) perencanaan media yang ada untuk meminimalisir kejadian dan memunculkan kesan yang positif, dan (6) perencanaan setelah kejadian dengan berbagai upaya yang membutuhkan pengembalian seperti sedia kala dari tempat wisata sebelum adanya kejadian yang merugikan. Bagan analisis kebutuhan manajemen bencana dapat dilihat di Gambar 9. 


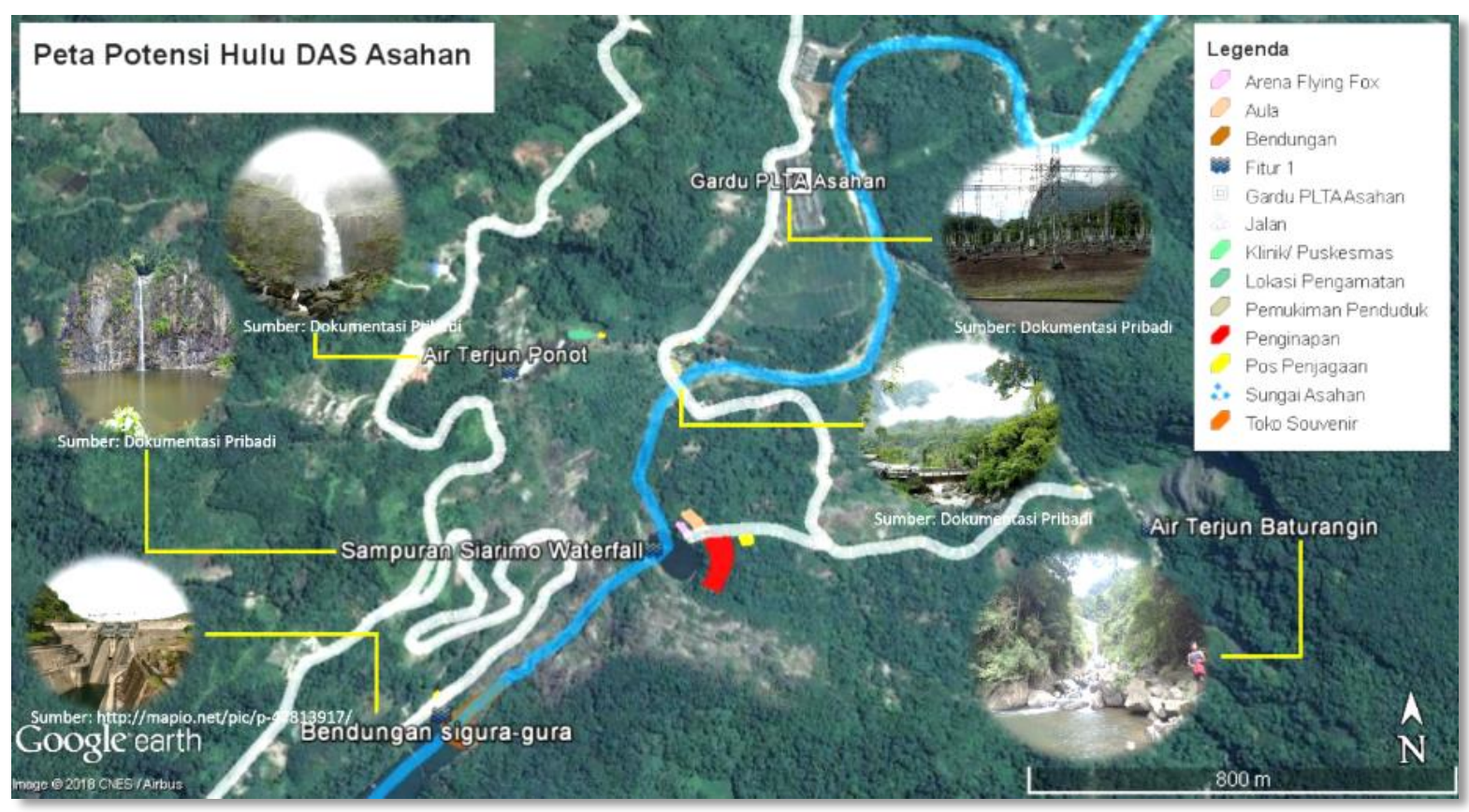

Gambar 8. Pemodelan Area Wisata Alam Potensi Eduwisata (Sumber: Hasil Analisis, 2019)

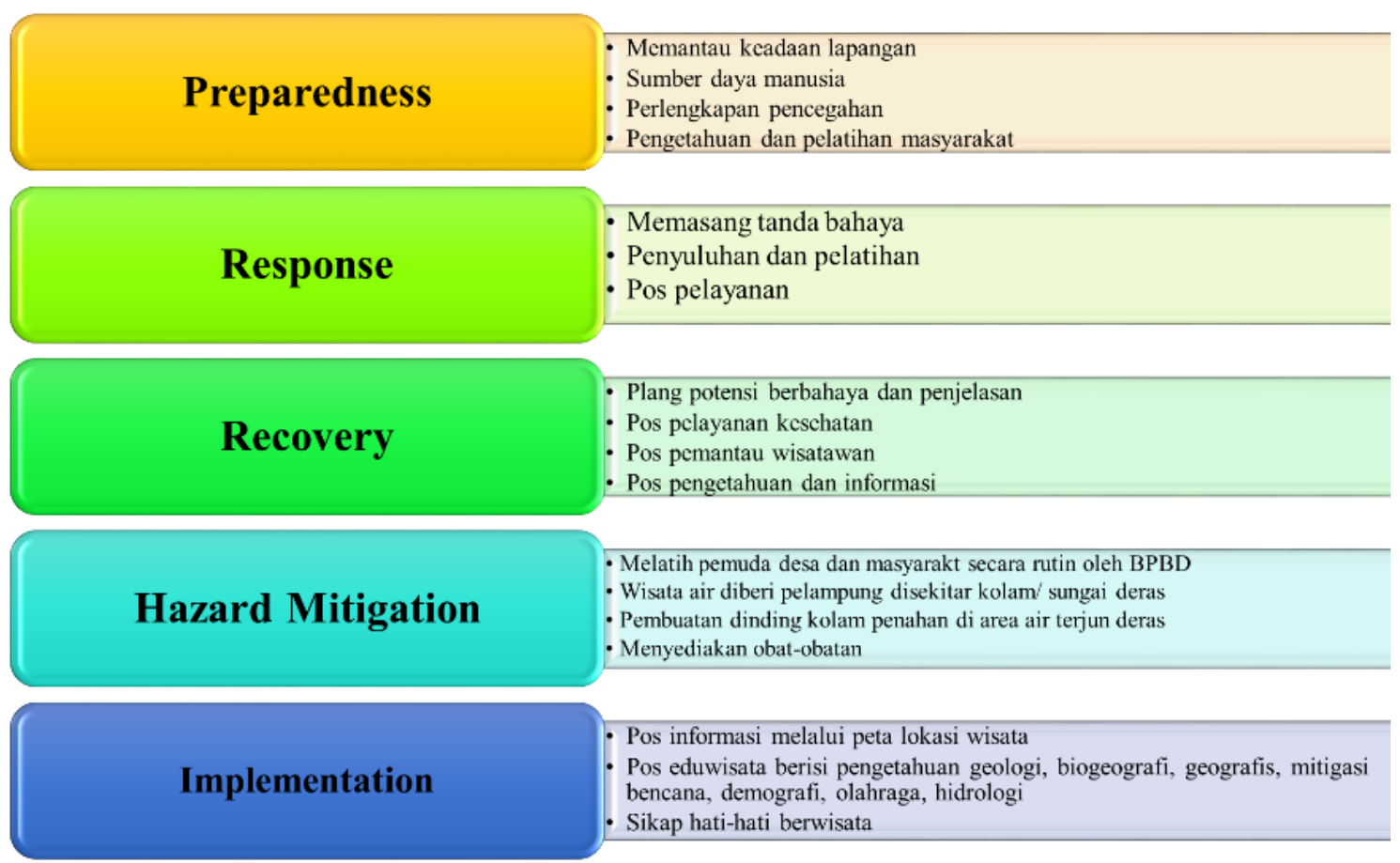

Gambar 9. Tahap Program Wisatawan Tanggap Bencana (Sumber: Hasil Analisis, 2019) 


\section{KESIMPULAN}

Potensi lokasi eduwisata Hulu DAS Asahan ialah jenis wisata hidrologi yang terdiri dari sungai, PLTA, dan air terjun. Potensi tersebut berlokasi di Sungai Asahan, Air Terjun Ponot, Air Terjun Siharimo, Air Terjun Baturangin, Bendungan Sigura-gura, dan Gardu PLTA Sigura-gura. Akses menuju potensi eduwisata melalui Desa Parhitean, Kecamatan Pintu Pohan, Kabupaten Samosir atau melalui jalur Desa Tangga, Kecamatan Aek Songsongan, Kabupaten Asahan.

Potensi aktivitas yang dapat dilakukan antara lain tracking, penelitian fisik dan sosial, olahraga, dan berkemah. Wisata yang berpotensi menarik perhatian pengunjung ialah Sungai Asahan, Air Terjun Ponot, Air Terjun Siharimo, Air Terjun Baturangin, Bendungan Sigura-gura, dan Gardu PLTA Asahan.

\section{UCAPAN TERIMA KASIH}

Terima kasih diucapkan kepada SMAS Panti Budaya Kisaran, Ganesha Operation Kisaran, dan Jurusan Pendidikan Geografi Unimed, yang telah membantu dalam penelitian ini.

\section{DAFTAR PUSTAKA}

Akhmedova, O O. 2016. "Educational Tourism: Defining the Concept." Repository KhNUE, Ukraine. Repository KhNUE, Ukraine.

BPDAS Barumun. 2016. "Peta Tanah DAS Barumun.”

FAJl.org. 2007. "FAJI.Org - Federasi Arung Jeram Indonesia | Event Asahan 2007." 2007.

http://www.faji.org/?go=event_asahan20 07\&p=hasil_h2h.

Heru. 2017. "Dua Pemuda Asahan Hanyut Di Air Terjun Jambu Ara, Ini Cerita Keluarga Korban."

Https:/NWww.Hetanews.Com/Article/9911

5/Dua-Pemuda-Asahan-Hanyut-Di-AirTerjun-Jambu-Ara-Ini-Cerita-KeluargaKorban. https://www.hetanews.com/article/99115/ dua-pemuda-asahan-hanyut-di-air-terjunjambu-ara-ini-cerita-keluarga-korban.

Yoeti, Oka. 1996. "Pengantar IImu Pariwisata." Bandung, Angkasa.

Yudistira, I G A Anom, and Nur Agus Susanto. 2012. "Rancangan Sistem Penilaian Keselamatan Pengunjung Tempat Wisata." Jurnal IImiah Widya. 
